\title{
Biological and physical characterization of the seabed surrounding Ascension Island from $100-1000 \mathrm{~m}$
}

\author{
E.T. NOLAN ${ }^{1}$, D.K.A. BARNES ${ }^{2}$, J. BROWN $^{1,3}$, K. DOWNES ${ }^{1}$, P. ENDERLEIN ${ }^{2}$, E. GOWLAND ${ }^{2}$, O.T. HOGG $^{2,4}$, \\ V. LAPTIKHOVSKY ${ }^{3,5}$, S.A. MORLEY ${ }^{2}$, R.J. MROWICKI ${ }^{1}$, A. RICHARDSON ${ }^{1}$, C.J. SANDS ${ }^{2}$, N. WEBER $^{1}$, \\ S. WEBER ${ }^{1}$ AND P. BRICKLE ${ }^{3,6,7}$ \\ ${ }^{1}$ Ascension Island Government, Conservation Department, Ascension Island, Saint Helena, ${ }^{2}$ British Antarctic Survey, NERC, \\ Madingley Road, Cambridge, UK, ${ }^{3}$ Shallow Marine Surveys Group, PO Box 609, Stanley, Falkland Islands, ${ }^{4}$ National Oceanography \\ Centre, NERC, Southampton, UK, ${ }^{5}$ Centre for Environmental Fisheries and Aquaculture Science, Lowestoft, UK, ${ }^{6}$ South Atlantic \\ Environmental Research Institute, Stanley, Falkland Islands, ${ }^{7}$ School of Biological Sciences (Zoology), University of Aberdeen, \\ Tillydrone Avenue, Aberdeen, Scotland, UK
}

\begin{abstract}
Recent studies have improved our understanding of nearshore marine ecosystems surrounding Ascension Island (central Atlantic Ocean), but little is known about Ascension's benthic environment beyond its shallow coastal waters. Here, we report the first detailed physical and biological examination of the seabed surrounding Ascension Island at $100-1000 \mathrm{~m}$ depth. Multibeam swath data were used to map fine scale bathymetry and derive seabed slope and rugosity indices for the entire area. Water temperature and salinity profiles were obtained from five Conductivity, Temperature, Depth (CTD) deployments, revealing a spatially consistent thermocline at $80 \mathrm{~m}$ depth. A camera lander (Shelf Underwater Camera System; SUCS) provided nearly 400 images from 21 sites (100 $\mathrm{m}$ transects) at depths of 110-1020 $\mathrm{m}$, showing high variability in the structure of benthic habitats and biological communities. These surveys revealed a total of 95 faunal morphotypes (mean richness $>14$ per site), complemented by 213 voucher specimens constituting 60 morphotypes collected from seven targeted Agassiz trawl (AGT) deployments. While total faunal density (maximum $>300 \mathrm{~m}^{-2}$ at $480 \mathrm{~m}$ depth) increased with rugosity, characteristic shifts in multivariate assemblage structure were driven by depth and substratum type. Shallow assemblages $(\sim 100 \mathrm{~m})$ were dominated by black coral (Antipatharia sp.) on rocky substrata, cup corals (Caryophyllia sp.) and sea urchins (Cidaris sp.) were abundant on fine sediment at intermediate depths $(250-500 \mathrm{~m}$ ), and shrimps (Nematocarcinus spp.) were common at greater depths $\left(>_{500} \mathrm{~m}\right)$. Other ubiquitous taxa included serpulid and sabellid polychaetes and brittle stars (Ophiocantha sp.). Cold-water corals (Lophelia cf. pertusa), indicative of Vulnerable Marine Ecosystems (VMEs) and representing substantial benthic carbon accumulation, occurred in particularly dense aggregations at $<350 \mathrm{~m}$ but were encountered as deep as $1020 \mathrm{~m}$. In addition to enhancing marine biodiversity records at this locality, this study provides critical baseline data to support the future management of Ascension's marine environment.
\end{abstract}

Keywords: Ascension Island, benthic shelf, marine biodiversity, tropical South Atlantic, Vulnerable Marine Ecosystems

Submitted 15 January 2016; accepted 24 April 2017

\section{INTRDDUCTIDN}

Ascension Island is a relatively young $(\sim 1 \mathrm{my}$; Jicha et al., 2013), South Atlantic Ocean island ( $\left.07^{\circ} 57^{\prime} \mathrm{S} 14^{\circ} 22^{\prime} \mathrm{W}\right)$ $\sim 80 \mathrm{~km}$ west of the mid-Atlantic ridge. It is extremely remote with its nearest neighbour St. Helena $1300 \mathrm{~km}$ to the south (Figure 1, inset). To date, most studies on the marine biodiversity surrounding the island have focussed on turtles (Weber et al., 2014), seabirds (Bourne \& Simmons, 2001) and shallow water coastal assemblages, typically located within depths less than $30 \mathrm{~m}$ (e.g. Price \& John, 1980; Brewin et al., 2016). The island's shallow marine biodiversity represents a unique assemblage of western and eastern

Corresponding author:

P. Brickle

Email: pbrickle@env.institute.ac.fk
Atlantic biota (Floeter et al., 2007; De Grave et al., in press; Tsiamis et al., 2017; Wirtz et al., 2017). The inshore fish community is characterized as extremely abundant with low species richness and relatively high levels of endemism when compared with other Atlantic oceanic islands (Floeter et al., 2007), probably due to its young age and isolation. In comparison, invertebrate richness and diversity still needs to be quantified but is inconspicuous owing to the abundance of fish (Brewin et al., 2016).

Habitat diversity in the shallow sub-littoral is comparatively limited. Being a small oceanic island $\left(97 \mathrm{~km}^{2}\right)$ with no enclosed bays or sheltered lagoons, the entire coastline of Ascension is subject to large Atlantic swells. Many typical tropical coastal habitats often associated with high biological diversity such as mangroves, seagrass beds and coral reefs are absent, and the coast is dominated by volcanic rock, rhodolith (maerl) pebble and sand substrates. Coralline algal rhodolith beds, which form the only substantial biogenic 


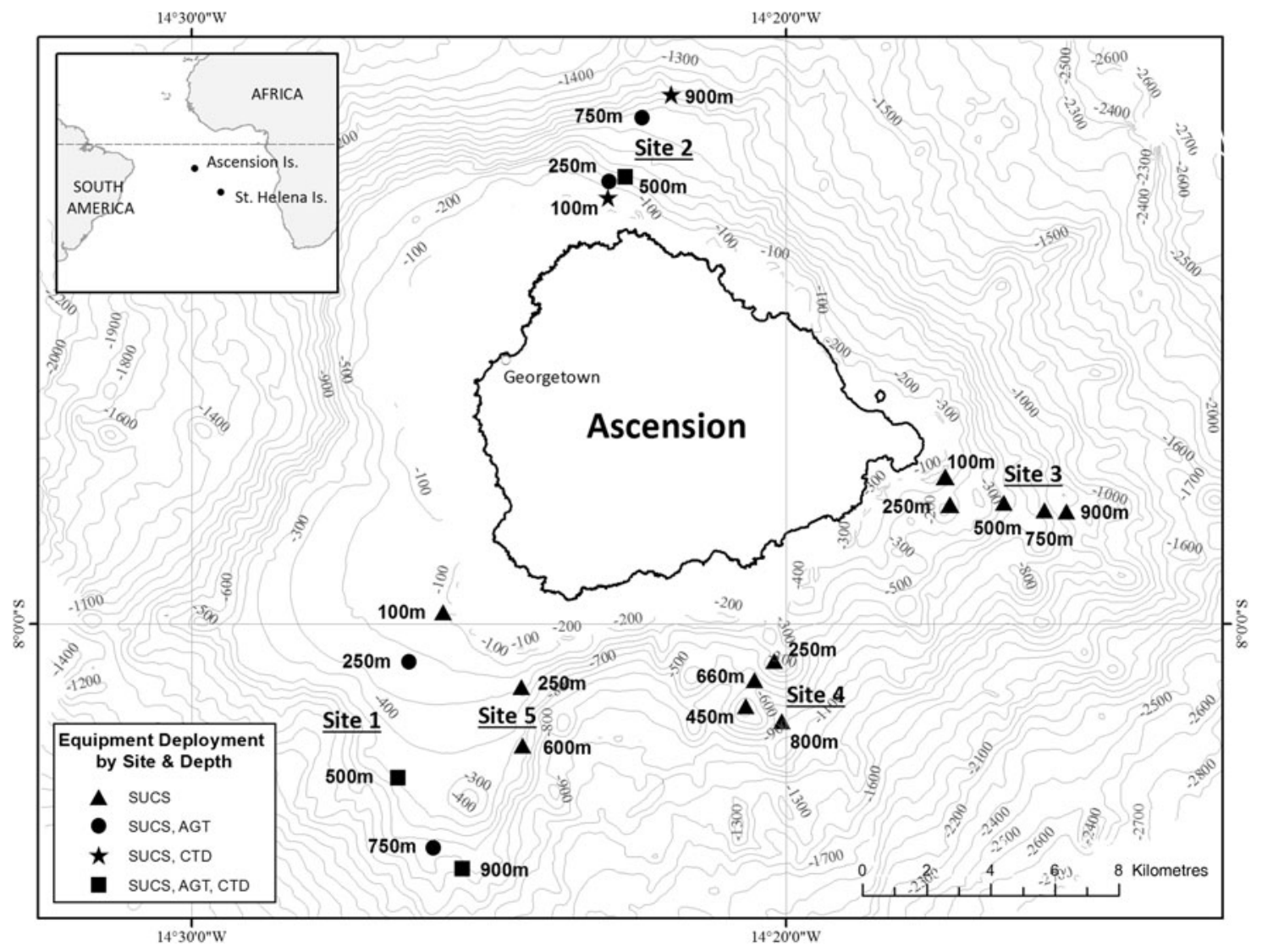

Fig. 1. Site locations showing equipment and depth. Inset: position of Ascension and St Helena Islands in the Atlantic Ocean.

three-dimensional habitat in shallow waters, are known to support a diverse infaunal community (Macaya et al., 2015; Neill et al., 2015; Torrano-Silva et al., 2015) as well as being important in carbon cycling (Nelson, 2009; Cavalcanti et al., 2014).

Although recent work has substantially advanced our understanding of Ascension's coastal marine environment (Darwin Initiative projects EIDCF012 and DPLUSo21), data on benthic communities and habitats below a depth of $30 \mathrm{~m}$ are still remarkably rare. The marine biota of Ascension has been of interest to scientists since the 19th century, with famous expeditions such as 'Challenger' and 'Discovery' visiting the island in 1876 and 1925 respectively (Manning \& Chace, 1990). These early scientific expeditions were among the only previously known attempts to systematically sample Ascension's deep-water benthos and although they contributed much to the identification of certain taxa, did little to improve our understanding of the ecology of the benthic marine environment. Given the narrow fringe of shallow, coastal water that is accessible to divers, much of Ascension's shelf ecosystem therefore remains largely undiscovered.

Knowledge of seafloor topography and habitats is similarly sparse. The UK Hydrographic Office navigational chart of the area is constructed from data collected between 1826 and 1984 and is focussed on areas surrounding the main anchorages. More complete coverage is provided by the General Bathymetric Chart of the Ocean (GEBCO), but resolution is coarse at 30 arc-seconds $\left(\sim_{2} \mathrm{~km}\right)$ and not sufficiently detailed for mapping variation in seabed topography at the scale typically of interest for ecological studies.

This study was developed as an objective of the Darwin Initiative-funded Ascension Island Marine Sustainability project (DPLUSo21) aimed at addressing some of the key knowledge gaps relating to Ascension Island's deeper water ecosystem and was conducted aboard the Natural Environment Research Council research vessel the Royal Research Ship 'James Clark Ross' (hereafter JCR) during 14-18 October 2015. The study's main objectives were: (1) to map Ascension Island's shelf seabed bathymetry and characterize spatial variation in seafloor structure and topography; (2) to identify, quantify and compare benthic assemblages to fine scale seabed characteristics between 100 and $1000 \mathrm{~m}$; and (3) to collect benthic specimens for identification from previously unsampled areas.

\section{MATERIALS AND METHDDS}

The sampling protocol utilized during the Ascension Island cruise (cruise identifier JR864) was adapted from previous continental shelf biodiversity survey expeditions conducted aboard the JCR (e.g. JR262 and JR287; Barnes et al., 2011, 2013) and incorporated four key aspects: (1) fine scale bathymetry (multibeam echosounder); (2) temperature and salinity profiles (Conductivity-Temperature-Depth [CTD]), (3) benthic habitats and faunal assemblages (Shelf 
Underwater Camera System [SUCS]) and (4) biological specimen collection (Agassiz trawl [AGT]).

\section{Fine scale bathymetry}

A Kongsberg EM122 multibeam system was used, run through the Kongsberg SIS software. The system was run in external trigger mode with the ping rate calculated by the Kongsberg Synchronization Unit (K-Sync). The number of cells in the processing grid was set to $128 \times 128$ and the grid cell size was set to $50 \mathrm{~m}$. Angular coverage mode was set to manual and beam spacing to high density equidistant. The maximum beam angle was varied from $50^{\circ}$ to $75^{\circ}$ depending on the sea state, water depth and bathymetry, often on the slope the uphill beam was extended much further than the downhill beam to try and maximize data capture.

In addition to water depth, several derived bathymetric datasets were also extracted from multibeam data to describe spatial variation in aspects of seabed structure and topography that may influence biological assemblages and species distributions. Derived datasets included slope, terrain ruggedness index (TRI) and topographic position index (TPI). Slope was calculated as a measure in degrees $\left(^{\circ}\right)$ of the inclination of the seabed using Landserf (version 2.3) multi-scale analysis. TRI is a measure of seabed rugosity calculated using SAGA
GIS (version 2.0) and is derived by comparing the 2-dimensional footprint area of the seabed versus the 3-dimensional area of the bathymetry dataset. A data point that differs in depth most from the mean depth of the surrounding cells will have the highest TRI. Topographic position index (TPI) is a local elevation index which measures the relative topographic position of each bathymetric point in relation to its neighbours. TPI is a useful tool in identifying landscape features and topographic boundaries at different spatial resolutions and provides an indication as to whether a site is located on a peak, in a valley or in a region of constant gradient. TPI was calculated using the Land Facet Corridor Tools extension for ArcGIS.

Data from derived bathymetric datasets were used to select five broad sampling site locations (Figure 1), representing as wide a range of bottom topography (or habitats) as possible over depths of 100 to $1000 \mathrm{~m}$ to deploy CTD, SUCS and AGT apparatus (Table 1).

\section{Temperature and salinity profiles}

A CTD unit was used to vertically profile the water column. The SBE9Plus unit held dual $\mathrm{SBE}_{3}$ Plus temperature and $\mathrm{SBE}_{4}$ conductivity sensors and a Paroscientific pressure sensor. The CTD was raised as close to the surface as sea conditions allowed and then lowered to within $10 \mathrm{~m}$ of the seabed.

Table 1. Site locations, depths and unique identifiers for all deployments.

\begin{tabular}{|c|c|c|c|c|}
\hline Event name & Latitude & Longitude & Depth (m) & SUCS photos \\
\hline SUCS $_{1}$ & $\mathrm{~S} 08^{\circ} 4^{\prime} 7.068^{\prime \prime}$ & W $14^{\circ} 25^{\prime} 26.904^{\prime \prime}$ & 880 & 20 \\
\hline SUCS 2 & $\mathrm{~S} 08^{\circ} 3^{\prime} 46.440^{\prime \prime}$ & $\mathrm{W} 14^{\circ} 25^{\prime} 56.208^{\prime \prime}$ & 770 & 20 \\
\hline SUCS $_{3}$ & $\mathrm{~S} 08^{\circ} 2^{\prime} 35.232^{\prime \prime}$ & $\mathrm{W}_{14}^{\circ} 26^{\prime} 31.740^{\prime \prime}$ & 500 & 20 \\
\hline SUCS $_{4}$ & $\mathrm{~S} 08^{\circ} \mathrm{o}^{\prime} 38.592^{\prime \prime}$ & $\mathrm{W} 14^{\circ} 26^{\prime} 21.012^{\prime \prime}$ & 220 & 20 \\
\hline SUCS $_{5}$ & $\mathrm{~S} 07^{\circ} 59^{\prime} 47.832^{\prime \prime}$ & W $14^{\circ} 25^{\prime} 46.236^{\prime \prime}$ & 110 & 20 \\
\hline AGT 1 & $\mathrm{~S} 08^{\circ} \mathrm{o}^{\prime} 31.104^{\prime \prime}$ & $\mathrm{W} 14^{\circ} 26^{\prime} 32.352^{\prime \prime}$ & 210 & \\
\hline AGT 2 & $\mathrm{~S} 08^{\circ} 2^{\prime} 33.288^{\prime \prime}$ & $\mathrm{W} 14^{\circ} 26^{\prime} 34.368^{\prime \prime}$ & 500 & \\
\hline $\mathrm{AGT}_{3}$ & $\mathrm{~S} 08^{\circ} 3^{\prime} 47.520^{\prime \prime}$ & W $14^{\circ} 26^{\prime} 0.960^{\prime \prime}$ & 770 & \\
\hline $\mathrm{AGT}_{4}$ & $\mathrm{~S} 08^{\circ} 3^{\prime} 59.796^{\prime \prime}$ & $\mathrm{W} 14^{\circ} 25^{\prime} 34.680^{\prime \prime}$ & 840 & \\
\hline $\mathrm{CTD}_{1}$ & $\mathrm{~S} 08^{\circ} 4^{\prime} 13.512^{\prime \prime}$ & $\mathrm{W} 14^{\circ} 25^{\prime} 20.352^{\prime \prime}$ & 880 & \\
\hline $\mathrm{CTD}_{2}$ & $\mathrm{~S} 08^{\circ} 2^{\prime} 27.744^{\prime \prime}$ & $\mathrm{W} 14^{\circ} 26^{\prime} 40.596^{\prime \prime}$ & 500 & \\
\hline $\mathrm{CTD}_{3}$ & $\mathrm{~S} 07^{\circ} 51^{\prime} 5.400^{\prime \prime}$ & $\mathrm{W} 14^{\circ} 21^{\prime} 56.592^{\prime \prime}$ & 960 & \\
\hline $\mathrm{CTD}_{4}$ & $\mathrm{~S} 07^{\circ} 52^{\prime} 29.748^{\prime \prime}$ & $\mathrm{W} 14^{\circ} 22^{\prime} 41.448^{\prime \prime}$ & 340 & \\
\hline $\mathrm{CTD}_{5}$ & $\mathrm{~S} 07^{\circ} 52^{\prime} 49.620^{\prime \prime}$ & $\mathrm{W} 14^{\circ} 23^{\prime} 0.240^{\prime \prime}$ & 120 & \\
\hline SUCS 6 & $\mathrm{~S} 07^{\circ} 52^{\prime} 49.476^{\prime \prime}$ & $\mathrm{W} 14^{\circ} 23^{\prime} 0.096^{\prime \prime}$ & 120 & 20 \\
\hline SUCS $7_{7}$ & $\mathrm{~S} 07^{\circ} 52^{\prime} 33.024^{\prime \prime}$ & $\mathrm{W} 14^{\circ} 22^{\prime} 59.088^{\prime \prime}$ & 260 & 20 \\
\hline SUCS 8 & $\mathrm{~S} 07^{\circ} 52^{\prime} 28.704^{\prime \prime}$ & $\mathrm{W} 14^{\circ} 22^{\prime} 42.780^{\prime \prime}$ & 340 & 20 \\
\hline SUCS 9 & $\mathrm{~S} 07^{\circ} 51^{\prime} 29.016^{\prime \prime}$ & $\mathrm{W} 14^{\circ} 22^{\prime} 25.464^{\prime \prime}$ & 750 & 20 \\
\hline SUCS 10 & $\mathrm{~S} 07^{\circ} 51^{\prime} 8.784^{\prime \prime}$ & $\mathrm{W} 14^{\circ} 22^{\prime} 0.156^{\prime \prime}$ & 890 & 20 \\
\hline AGT 5 & $\mathrm{~S} 07^{\circ} 51^{\prime} 29.88 \mathrm{o}^{\prime \prime}$ & $\mathrm{W} 14^{\circ} 22^{\prime} 31.764^{\prime \prime}$ & 750 & \\
\hline AGT 6 & $\mathrm{~S} 07^{\circ} 52^{\prime} 29.388^{\prime \prime}$ & $\mathrm{W} 14^{\circ} 22^{\prime} 48.108^{\prime \prime}$ & 330 & \\
\hline $\mathrm{AGT}_{7}$ & $\mathrm{~S} 07^{\circ} 52^{\prime} 33.600^{\prime \prime}$ & $\mathrm{W} 14^{\circ} 22^{\prime} 53.940^{\prime \prime}$ & 230 & \\
\hline SUCS 11 & $\mathrm{~S} 07^{\circ} 57^{\prime} 31.032^{\prime \prime}$ & W $14^{\circ} 17^{\prime} 19.248^{\prime \prime}$ & 110 & 20 \\
\hline SUCS 12 & $\mathrm{~S} 07^{\circ} 57^{\prime} 59.112^{\prime \prime}$ & W $14^{\circ} 17^{\prime} 15.000^{\prime \prime}$ & 210 & 20 \\
\hline SUCS $_{13}$ & $\mathrm{~S} 07^{\circ} 57^{\prime} 57.744^{\prime \prime}$ & W $14^{\circ} 16^{\prime} 20.496^{\prime \prime}$ & 500 & 20 \\
\hline SUCS 14 & $\mathrm{~S} 07^{\circ} 58^{\prime} 4.944^{\prime \prime}$ & W $14^{\circ} 15^{\prime} 39.420^{\prime \prime}$ & 800 & 20 \\
\hline SUCS $_{15}$ & $\mathrm{~S} 07^{\circ} 58^{\prime} 6.060^{\prime \prime}$ & $\mathrm{W} 14^{\circ} 15^{\prime} 17.172^{\prime \prime}$ & 1020 & 11 \\
\hline SUCS 16 & $\mathrm{~S} 08^{\circ} 0^{\prime} 37.404^{\prime \prime}$ & $\mathrm{W} 14^{\circ} 20^{\prime} 12.228^{\prime \prime}$ & 280 & 20 \\
\hline SUCS 17 & $\mathrm{~S} 08^{\circ} 0^{\prime} 56.664^{\prime \prime}$ & $\mathrm{W} 14^{\circ} 20^{\prime} 31.776^{\prime \prime}$ & 670 & 20 \\
\hline SUCS 18 & S $08^{\circ} 1^{\prime} 22.944^{\prime \prime}$ & $\mathrm{W} 14^{\circ} 2 \mathrm{O}^{\prime} 40.920^{\prime \prime}$ & 480 & 20 \\
\hline SUCS 19 & $\mathrm{~S} 08^{\circ} 1^{\prime} 38.172^{\prime \prime}$ & $\mathrm{W} 14^{\circ} 20^{\prime} 4.452^{\prime \prime}$ & 850 & 20 \\
\hline SUCS 20 & $\mathrm{~S} 08^{\circ} 1^{\prime} 3.828^{\prime \prime}$ & $\mathrm{W} 14^{\circ} 24^{\prime} 27.540^{\prime \prime}$ & 280 & 20 \\
\hline $\operatorname{SUCS} 21^{\mathrm{a}}$ & $\mathrm{S} 08^{\circ} 2^{\prime} 2.400^{\prime \prime}$ & $\mathrm{W} 14^{\circ} 24^{\prime} 25.884^{\prime \prime}$ & 500 & 7 \\
\hline
\end{tabular}

${ }^{\mathrm{a}}$ Excluded from analyses owing to small sample size. 
CTD data was collected using software Seasave Win32 (Sea-Bird Electronics, Inc). A total of five CTD deployments were undertaken (Table 1), two from the south-west of Ascension at depths of 900 and $500 \mathrm{~m}$, and three to the north of the island at depths of 900,300 and $100 \mathrm{~m}$ (Figure 1). CTD deployments did not take place at other locations due to time constraints.

\section{Benthic habitats and faunal assemblages}

The SUCS was used as a tool allowing insight into the conditions of the underwater landscape and investigation of the micro-scale topography of the benthic environment. SUCS imagery can also be used to estimate faunal richness and density of the benthos.

The SUCS consists of three units: (1) the laboratory-based imaging control; PC with monitor (for camera and lighting control), a cable-metering sheave indicator and deck box; (2) the deck-based deployment control; winch, underwater cable, deck monitor and metering sheave on the mid-ships gantry; and (3) the underwater camera lander unit; tripod frame with underwater housed video and stills camera, booster and power distribution board and the underwater lights.

The SUCS was deployed from the mid-ships gantry on a fibre-optic cable connected to a motorized winch system, dropping at a rate of $30 \mathrm{~m} \mathrm{~min}^{-1}$ until it sat and stabilized on the seabed, video and photo stills were taken using the SUCS software. The system allows high-resolution photo stills $(2448 \times 2050$ pixels), with a field of view fixed to $0.25 \mathrm{~m}^{-2}$ on a flat surface, and video footage $(2448 \times 2050$ pixels) to be taken simultaneously that produces a live feed in full colour and in HD $(2448 \times 2050$ pixels $)$. A photo was taken as soon as the system was settled on the seabed, the system was then lifted clear of the bed and moved $\sim 5 \mathrm{~m}$ in one direction, this was repeated to achieve 20 photos (i.e. $5 \mathrm{~m}^{-2}$ ) taken over an approximate horizontal distance of $100 \mathrm{~m}$. The SUCS was deployed a total of 21 times at approximate depths of 100, 250, 500, 750 and $900 \mathrm{~m}$ (Table 1).

Sessile and mobile benthic fauna observed in SUCS photos were distinguished according to morphotype, as a proxy for taxonomic group (species, genus or class), and enumerated. To allow faunal assemblage structure to be related to benthic habitat characteristics, SUCS photos were categorized according to (1) roughness, on a scale from o (smooth mud or fine sand) to 5 (complex 3-dimensional cover), and (2) dominant substratum type, on a scale from o (silt) to 8 (boulders or bedrock; Table 2).

\section{Data analyses}

For each transect, faunal counts were summed and divided by accumulated photo area to obtain densities of individual morphotypes, which were used to calculate morphotype richness $(S)$ and evenness (Simpson's $1-\lambda$ ) (Table 3). Owing to an exceptionally low sample size $(\mathrm{N}=7)$, the $500 \mathrm{~m}$-depth transect at site 5 (SUCS21) was excluded from further analyses.

Transects were ranked according to average roughness, determined from the mean of the ordinal roughness categories (Table 2) assigned to individual photos. Additionally, the relative proportions of photos within the nine substratum categories (Table 2) were used to estimate the per cent cover of different substrata (i.e. silt, fine sand, coarse sand, small
Table 2. Classifications used for roughness and substratum identification across SUCS imagery.

\begin{tabular}{ll}
\hline Roughness & \multicolumn{1}{c}{ Description } \\
\hline 0 & Completely smooth (mud/fine sand) \\
1 & Sand waves/ripples/small pebbles \\
2 & Scattered rocks \\
3 & Scattered larger rocks/bedrock \\
4 & Scattered larger rocks/bedrock covering $>50 \%$ of image \\
5 & Complex 3-D cover \\
\hline Substratum & \\
\hline 0 & \\
1 & Silt \\
2 & Fine sand \\
3 & Coarse sand \\
4 & Fine pebbles \\
5 & Coarse pebbles \\
6 & Cobbles \\
7 & Rocks \\
8 & Large rocks \\
\hline
\end{tabular}

pebbles, large pebbles, cobbles, small rocks, large rocks and boulders/bedrock) along each transect. Thus, nine separate variables, each representing the per cent cover of a different substratum type, were assigned to individual transects.

Subsequent analyses focussed on the relationships of environmental variables (transect depth, average roughness and percent cover of substrata) with (1) univariate faunal abundance and diversity indices (average density [i.e. the sum of the densities of individual morphotypes], richness and evenness of morphotypes, each represented by a single value per transect) and (2) multivariate faunal assemblage structure.

Table 3. SUCS transect depths, average faunal densities and univariate diversity indices (morphotype richness and evenness). Density, richness and evenness are overall values calculated for each transect as a whole; richness is not standardized by transect area.

\begin{tabular}{|c|c|c|c|c|}
\hline Transect & Depth (m) & Density $\left(\mathbf{m}^{-2}\right)$ & Richness (S) & $\begin{array}{c}\text { Evenness } \\
(1-\lambda)\end{array}$ \\
\hline SUCS $_{1}$ & 880 & 1.2 & 4 & 0.72 \\
\hline $\mathrm{SUCS}_{2}$ & 770 & 3.6 & 8 & 0.82 \\
\hline $\mathrm{SUCS}_{3}$ & 500 & 3.6 & 10 & 0.86 \\
\hline $\mathrm{SUCS}_{4}$ & 220 & 7.8 & 12 & 0.77 \\
\hline $\mathrm{SUCS}_{5}$ & 110 & 24.6 & 9 & 0.48 \\
\hline SUCS6 & 120 & 6.4 & 13 & 0.81 \\
\hline $\mathrm{SUCS}_{7}$ & 260 & 23.8 & 23 & 0.89 \\
\hline SUCS8 & 340 & 17.2 & 20 & 0.87 \\
\hline SUCS9 & 750 & 1.4 & 6 & 0.82 \\
\hline SUCS $_{10}$ & 890 & 4.6 & 14 & 0.91 \\
\hline SUCS $_{11}$ & 110 & 21.2 & 16 & 0.55 \\
\hline SUCS $_{12}$ & 210 & 41.4 & 24 & 0.65 \\
\hline SUCS $_{13}$ & 500 & 154.8 & 19 & 0.11 \\
\hline SUCS $_{14}$ & 800 & 43.2 & 19 & 0.41 \\
\hline SUCS $_{15}$ & 1020 & 6.5 & 11 & 0.88 \\
\hline $\operatorname{SUCS}_{16}$ & 280 & 46.4 & 24 & 0.63 \\
\hline SUCS $_{17}$ & 670 & 2.6 & 10 & 0.88 \\
\hline $\operatorname{SUCS}_{18}$ & 480 & 313.8 & 18 & 0.08 \\
\hline SUCS $_{19}$ & 850 & 22.8 & 16 & 0.72 \\
\hline SUCS2O & 280 & 19 & 15 & 0.82 \\
\hline $\mathrm{SUCS}_{21}$ & 500 & $34 \cdot 3$ & 13 & 0.72 \\
\hline
\end{tabular}


Spearman rank correlations were used to determine whether average density, richness and evenness varied with transect depth and average roughness. For the purpose of these analyses, richness was standardized by transect area to account for differences in the number of photos among transects (i.e. between SUCS $_{15}$ and the others). To test for relationships between the same three univariate indices and substratum characteristics, Mantel tests were performed on Euclidean distance matrices derived from both response data and multivariate substratum per cent cover data (i.e. nine variables), with 9999 permutations of the response matrix to evaluate significance (Legendre \& Legendre, 2012).

Prior to multivariate analyses, pairwise Spearman rank correlations were used to assess the extent of collinearity among environmental variables (i.e. average roughness and nine substratum variables). Average roughness showed strong $(\rho|\geq| 0.70)$ positive correlations with per cent cover of small rocks $(r=0.85)$ and large rocks $(r=0.79)$; therefore, roughness was excluded from further analyses. Subsequently, the biota-environment (BIOENV; Clarke \& Ainsworth, 1993) routine was used to identify the optimal subset of environmental variables accounting for variability in faunal assemblage structure, via maximization of the rank correlation between environmental and biological distance matrices. The variables identified by the BIOENV analysis were then used in a canonical analysis of principal coordinates (CAP Anderson \& Willis, 2003) to enable dissimilarities in faunal assemblages among transects to be visualized in the context of key environmental variables. The resulting ordination plot incorporated vectors representing Spearman rank correlations between environmental variables and the first two CAP axes. The significance of the overall model (based on the sum of all eigenvalues) and of constraining variables (marginal terms) were assessed via ANOVA-like permutation tests involving 9999 permutations. Spearman rank correlation coefficients between individual morphotype densities and CAP axes (Anderson \& Willis, 2003) were calculated to identify the most important morphotypes (i.e. $|\rho| \geq 0.5$ ) contributing to variability in assemblage structure. Additionally, nonmetric multidimensional scaling (nMDS) plots, unconstrained by environmental variables, were produced to show the overall pattern of faunal dissimilarities and variation in morphotype densities among transects.

Multivariate analyses were performed using Euclidean distances calculated from environmental data, which were $z$-standardized to account for scaling differences between depth and substratum variables, and Bray-Curtis dissimilarities calculated from individual morphotype densities, which were $\log _{10}(x+1)$-transformed to downweight the influence of numerically dominant species. Exclusion of rare morphotypes (i.e. overall mean density $\leq 0.01 \mathrm{~m}^{-2}$ ) did not alter results substantially; therefore, analyses incorporated all morphotypes.

All analyses were conducted in $R$ (version 3.2.0; $\mathrm{R}$ Core Team, 2015), in particular, using the functions mantel(), bioenv() and capscale() in the vegan package (version 2.3-5; Oksanen et al., 2016).

\section{Benthic specimen collection}

An Agassiz trawl (AGT) was used to sample the larger macroand mega-fauna from the benthic environment. The AGT had a mesh size of $1 \mathrm{~cm}$ and a mouth width of $2 \mathrm{~m}$. The cable length used was 1.5 times the water depth and was towed at 1 knot for 5 min from the ship's stern. The AGT was deployed seven times across depths of $\sim 250,500,750$ and $900 \mathrm{~m}$ (Table 1), where practicable, given the steep and abrasive topography. Samples were brought on-board and identified according to lowest possible taxonomic unit. Subsequent analysis of samples and photography records were undertaken back at the Ascension Island Government Fisheries Laboratory in the days following the cruise. Specimens that could not be identified were sent to taxonomic specialists.

\section{RESULTS}

\section{Fine scale bathymetry}

Near-complete bathymetric coverage for ocean depths from 100 to $1000 \mathrm{~m}$ around Ascension Island resulted from the survey (data available on request from the Polar Data Centre). Typically, the seabed is a narrow extension radiating from the island to a depth of $\sim 450 \mathrm{~m}$ (Figure $2 \mathrm{~A}$ ). On the north-west and especially the south-west of the island, the seabed extends out to $450 \mathrm{~m}$ in a plateau which at its widest point is $7 \mathrm{~km}$ offshore, beyond $450 \mathrm{~m}$ depth the angle of the slope of the seabed increases considerably reaching $1000 \mathrm{~m}$ depth within $1 \mathrm{~km}$ (Figure $2 \mathrm{~B}$ ). This drop-off is most pronounced along the north-west coast of the island (and to the east of the large south-eastern plateau) where the seabed inclination reaches a near-vertical $78^{\circ}$. The slope around the island is punctuated by large topographic features rising from depths over $1000 \mathrm{~m}$ to, in places on the south coast, as shallow as $250 \mathrm{~m}$. This complexity in the topography creates regions of high rugosity (roughness) over broad spatial scales $(50 \mathrm{~m})$ (Figure $2 \mathrm{C}$ ) and large variation in TPI (Figure $2 \mathrm{D}$ ), which may equate to greater habitat variability.

\section{Temperature and salinity profiles}

Temperature profiles around Ascension were characterized by warm surface waters $\left(24^{\circ} \mathrm{C}\right)$, with the top $80 \mathrm{~m}$ of the water column falling in a narrow temperature range of $22-24{ }^{\circ} \mathrm{C}$. A sharp thermocline at $\sim 80 \mathrm{~m}$ was identified at all deployments, with temperatures rapidly dropping to $17^{\circ} \mathrm{C}$ and then continuing to drop to $\sim 12{ }^{\circ} \mathrm{C}$ by $200 \mathrm{~m}$. Below $200 \mathrm{~m}$ water temperature decreased to $10{ }^{\circ} \mathrm{C}$ at $300 \mathrm{~m}, 8{ }^{\circ} \mathrm{C}$ at $500 \mathrm{~m}$ and $5{ }^{\circ} \mathrm{C}$ at $900 \mathrm{~m}$. At all deployments temperatures were seen to stabilize at $\sim 5{ }^{\circ} \mathrm{C}$ below $800 \mathrm{~m}$ (Figure 3 ).

Salinity was recorded at 36.2 psu from o-40 $\mathrm{m}$ water depth at all sites. Salinity increased between 50 and $60 \mathrm{~m}$, peaking at $\sim 36.5 \mathrm{psu}$, before decreasing with depth to $\sim 35.0 \mathrm{psu}$ at $200 \mathrm{~m}$. Salinity stabilized at $34.5 \mathrm{psu}$ deeper than $600 \mathrm{~m}$ (Figure 3).

\section{Benthic habitats and faunal assemblages}

A total of 95 morphotypes were distinguished using SUCS footage obtained from depths of 110-1020 m, of which 57 could be assigned preliminarily to genus, representing 21 identifiable classes within 12 Phyla (Supplementary Material, Table $\mathrm{S}_{1}$ ). Images revealed a series of characteristic faunal assemblages associated with particular substratum types that varied across the range of depths sampled (Figure $4 \mathrm{~A}-\mathrm{F}$ ). Across all 21 transects, mean $( \pm S E)$ average faunal density 

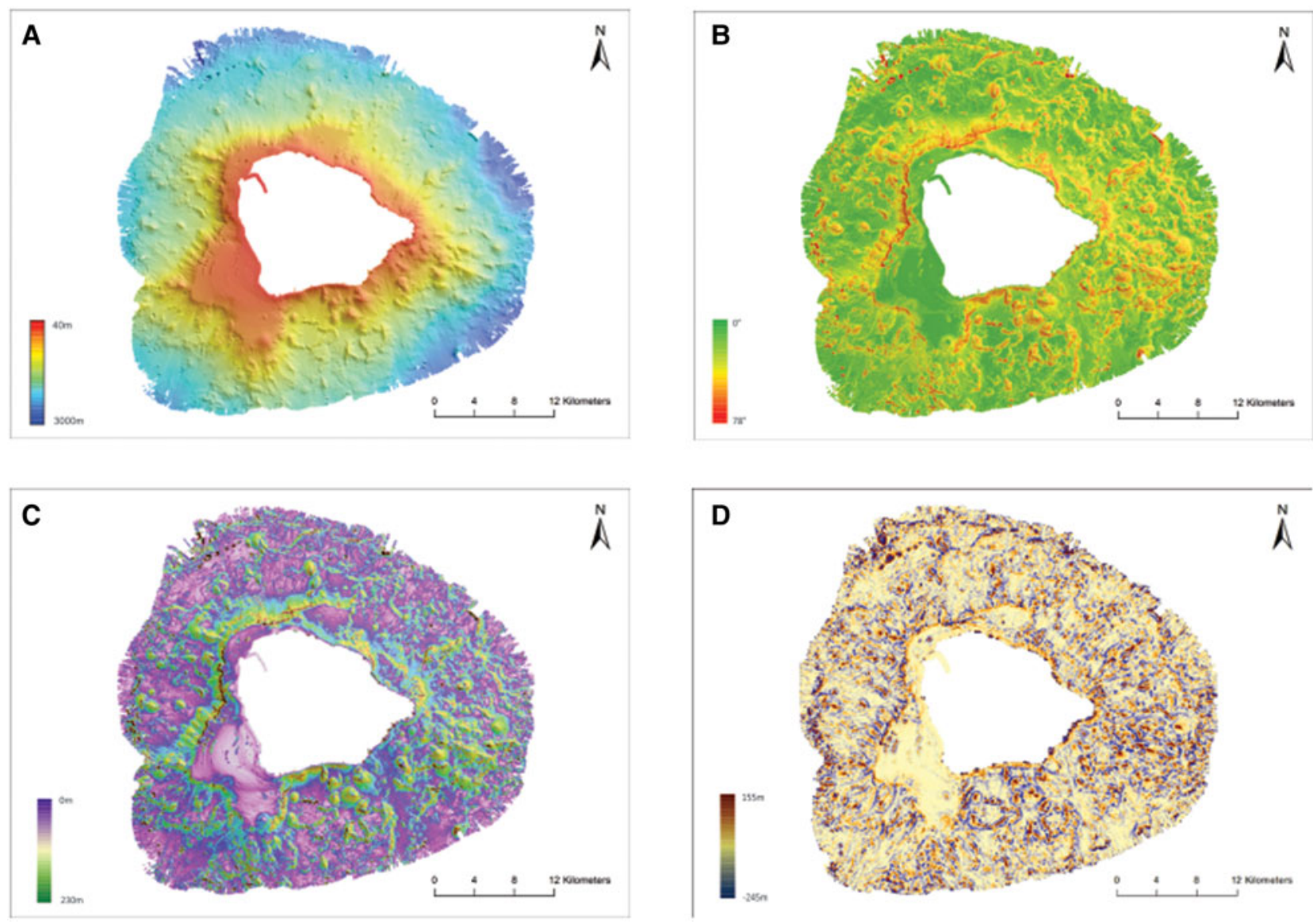

Fig. 2. (A) Bathymetry dataset gridded to $50 \mathrm{~m}$ resolution; (B) the measure in degrees $\left({ }^{\circ}\right)$ of the inclination of the seabed; (C) Terrain Ruggedness Index (TRI); (D) Topographic position index (TPI).

was $38.1 \pm 15.6 \mathrm{~m}^{-2}$ (range $1.2-313.8$ ), while mean morphotype richness and evenness were $14.5 \pm 1.3(4-24)$ and $0.7 \pm 0.1(0.1-0.9)$, respectively (Table 3 ).

The most abundant morphotype was the brittle star Ophiacantha sp., observed on 10 transects, with an overall mean $\left( \pm \mathrm{SE}\right.$ ) density of $22.2 \pm 15.6 \mathrm{~m}^{-2}$ (maximum $300.6 \mathrm{~m}^{-2}$, transect $\mathrm{SUCS}_{18}$; Figure $4 \mathrm{C}$ ). Other relatively abundant morphotypes were sabellid polychaetes (2.6 \pm $1.7 \mathrm{~m}^{-2}$; Figure ${ }_{4} \mathrm{E}$ ), black corals (Antipatharia sp.; $1.5 \pm$ $1.0 \mathrm{~m}^{-2}$; Figure $4 \mathrm{~A}$ ) and, on particular transects, squat lobsters identified as Munida microphthalma $\left(2.8 \mathrm{~m}^{-2}\right.$, SUCS 18 ) and a shrimp-like giant mysid, likely Gnathophausia zoea $\left(1.8 \mathrm{~m}^{-2}\right.$, SUCS7 and SUCS 16$)$.

Polychaetes identified as Serpula sp. (mean density $1.3 \pm$ $1.1 \mathrm{~m}^{-2}$ ) represented the most widespread morphotype, observed on 12 transects. Other commonly encountered morphotypes ( $\geq 10$ transects $)$ included the shrimp Nematocarcinus sp. (0.4 $\pm 0.1 \mathrm{~m}^{-2}$; Figure $\left.4 \mathrm{D}\right)$ and scleractinian corals belonging to the genera Caryophyllia (1.6 \pm $1.3 \mathrm{~m}^{-2}$; Figure $\left.4 \mathrm{~B}\right)$ and Lophelia cf. pertusa (1.1 \pm $0.4 \mathrm{~m}^{-2}$; Figure ${ }_{4} \mathrm{~F}$ ).

The only significant relationship found with respect to average faunal density was that it correlated positively with average roughness $(\rho=0.51, P=0.021)$. There was no correlation between average density and either substratum characteristics (Mantel test; $\rho=-0.03, P=0.578$ ) or depth $(\rho=-0.38, P=0.097)$, but there was an apparent peak in density at $480-500 \mathrm{~m}$, driven by elevated densities of
Ophiacantha sp. within transects SUCS $_{13}$ and SUCS 18 (Table 3; Figure 4C). Neither morphotype richness nor evenness correlated significantly with either depth (richness: $\rho=-0.17, P=0.461$; evenness: $\rho=0.32, P=0.176$ ) or substratum (richness: $\rho=0.06, P=0.225$; evenness: $\rho=-0.05$, $P=0.654)$. Further, while evenness was not related to roughness $(\rho=-0.27, P=0.258)$, there was only a marginally significant positive correlation between richness and roughness $(\rho=0.41, P=0.075)$.

Transect depth and per cent cover of coarse sand and large pebbles were identified as the most important environmental variables underlying variability in faunal assemblages (BIOENV; $\rho=0.65)$. All three constraints in the CAP were significant (depth: pseudo- $F_{1,16}=3.35, \quad P<0.001$; coarse sand: pseudo- $F_{1,16}=2.90, P<0.001$; large pebbles: pseudo- $\left.F_{1,16}=1.87, P=0.012\right)$. Depth showed a strong negative correlation with CAP axis $1(\rho=-0.90)$, the converse of which was true for per cent cover of pebbles (Figure $5 \mathrm{~A}$ ). The importance of depth in explaining overall dissimilarities among faunal communities was also emphasized by the unconstrained MDS plot (Figure 6A). Per cent cover of sand correlated positively with CAP axis $2(\rho=0.65)$, which separated transects with the lowest average roughness (i.e. SUCS 1 , $3,4,7,9$ and 17) from the rest of the samples (Figure 5A).

A total of nine morphotypes showed strong relationships $(|\rho| \geq 0.5)$ with CAP axes 1 and 2 (Figure ${ }_{5} \mathrm{~B}$ ). Deeper transects were associated with greater densities of Nematocarcinus sp., which was not found shallower than $500 \mathrm{~m}$ (Figure 6B), 

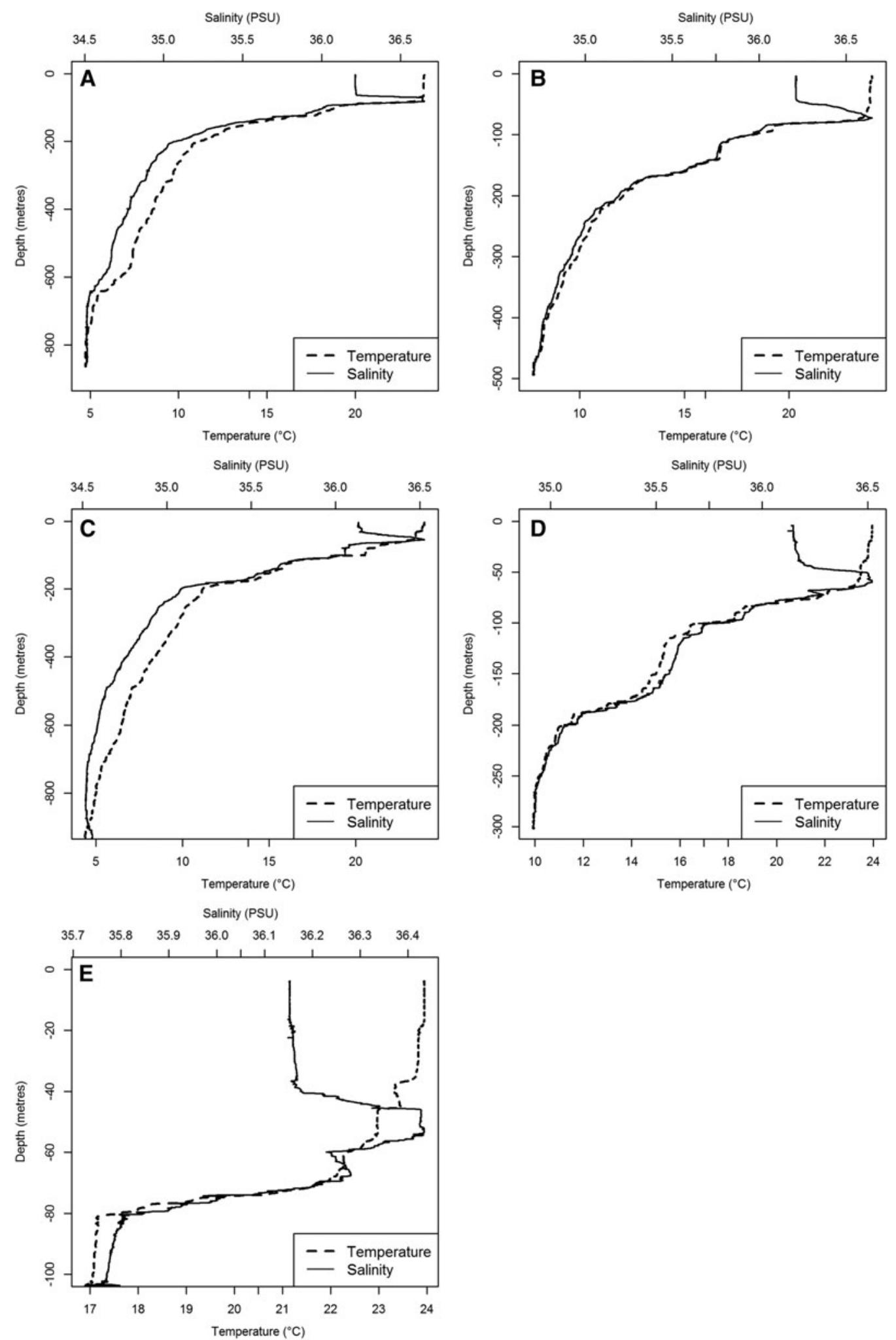

Fig. 3. CTD derived temperature and salinity profiles for each of the five deployments: (A) CTD 1; (B) CTD 2; (C) CTD 3; (D) CTD 4; (E) CTD 5.

and, to a lesser extent, sabellid polychaete and crinoid morphotypes (Figures $4 \mathrm{E} \& 6 \mathrm{C}, \mathrm{D}$ ). While sabellid polychaetes reached relatively high densities at $800-850 \mathrm{~m}$ depth (SUCS14 and SUCS19; Figure 6C), they were also found on shallower transects with lower per cent cover of sand (Figure 5A). Antipatharia sp. and orange encrusting sponge
(Demospongiae sp. indet.; Figure 6E) were more characteristic of shallower transects (Figure 4A) with greater per cent cover of pebbles. Although the density of Serpula sp. was partly related to depth (Figure 6B), this morphotype was abundant on shallower, less sandy transects (e.g. SUCS12; Figure 6F). Where present, the sea pen Virgularia sp. was more abundant 

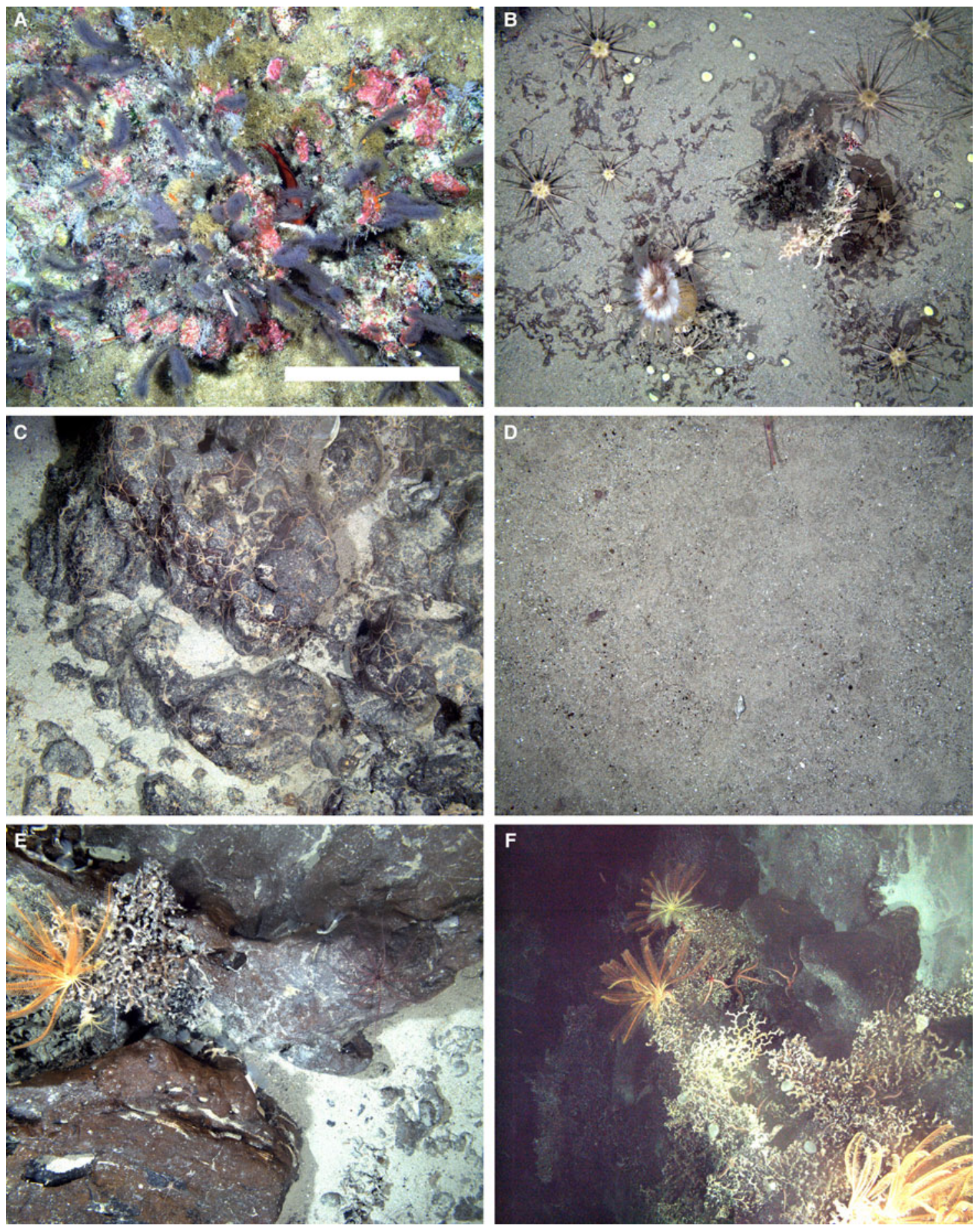

Fig. 4. Representative SUCS images of benthic habitats across a range of depths: (A) rocky substrata covered with black coral (Antipatharia sp.), encrusting algae and orange sponge (Demospongiae) at $100 \mathrm{~m}$ (transect $\mathrm{SUCS}_{5}$ ); (B) fine sediment with abundant sea urchins (Cidaris sp.) and scleractinian corals (Caryophyllia sp.) at $250 \mathrm{~m}$ (SUCS16); (C) large rocks with high densities of brittle stars (Ophiacantha sp.) at 450 m (SUCS18); (D) coarse sediment and fine pebbles inhabited by sea pens (Virgularia sp.), shrimps (Nematocarcinus sp.) and gastropod molluscs at $500 \mathrm{~m}$ (SUCS 3 ); (E) large rocks associated with sabellid polychaetes and feather stars (Crinoidea) at $700 \mathrm{~m}$ (SUCS14); (F) boulders and bedrock supporting reefs of the scleractinian coral Lophelia sp. at $800 \mathrm{~m}\left(\mathrm{SUCS}_{19}\right)$. Scale bar represents $20 \mathrm{~cm}$.

on transects with a higher per cent cover of sand (Figures $4 \mathrm{D}$ \& 6B).

\section{Benthic specimen collection}

In all, the 213 specimens collected were identified into 60 morphotypes (Supplementary Material, Table S2). Samples were separated by class as follows (including the number of specimens collected in each case): Alcyonaria (4), Anthozoa (3), Bivalvia (3), Brachiopoda (2), Cirripedia (4), Crinoidea (11), Crustacea (21), Demospongia (11), Echinoidea (7), Gastropoda (5), Hexactinalida (8), Hydrozoa (2), Malacostraca (57), Ophiuridae (20), Pisces (9), Polychaetes (18), Scyphozoa (6), Sipunculida (2), Thaliacea (2), 

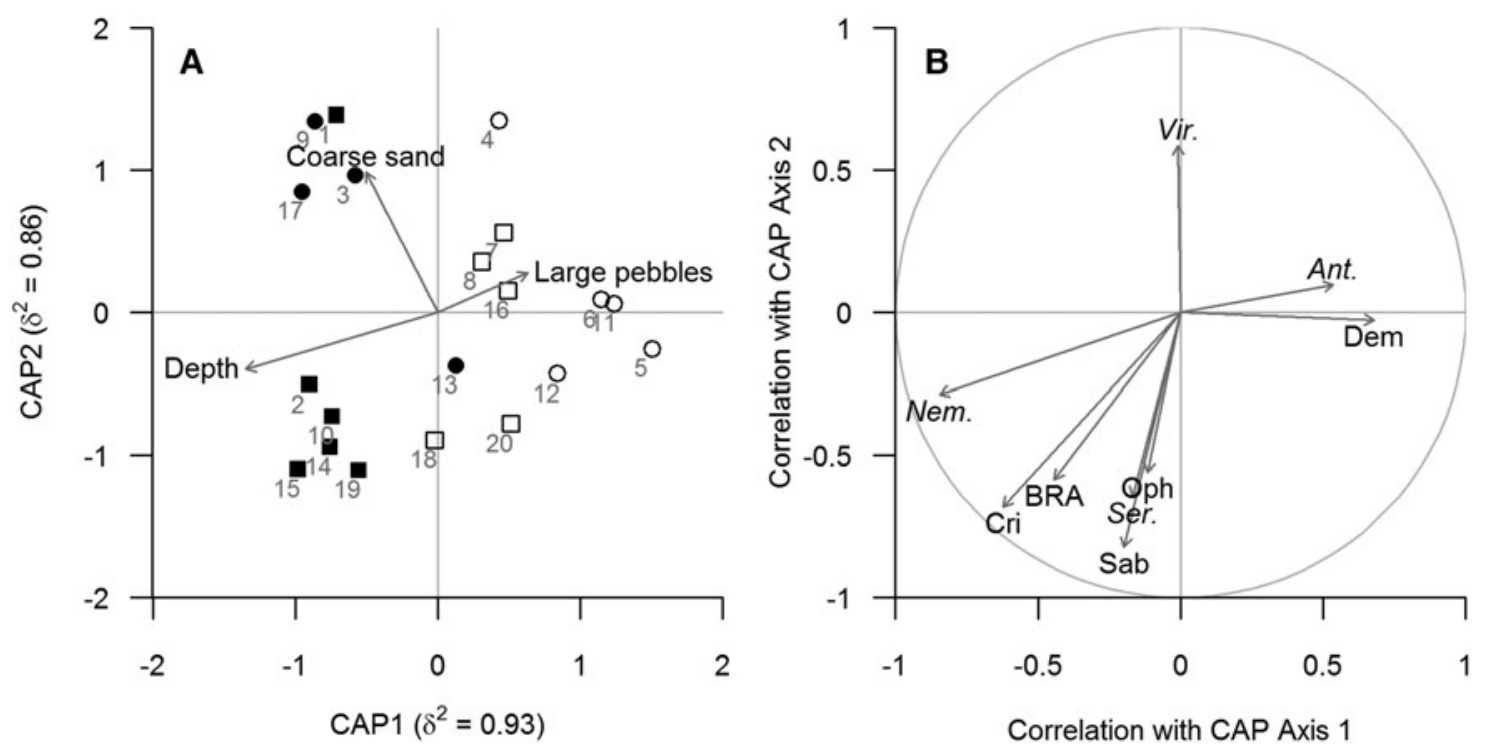

Fig. 5. (A) CAP ordination plot of faunal assemblage structure according to environmental variables (vectors represent Spearman rank correlation coefficients with axes). Point labels correspond to SUCS transect number and symbols depth category $(\mathrm{O}, 100-249 \mathrm{~m} ; \square, 250-499 \mathrm{~m} ; \mathbf{0}, 500-750 \mathrm{~m} ; \mathbf{\square},>750 \mathrm{~m})$. (B) Spearman rank correlation coefficients between CAP axes and individual morphotypes for which $|\rho| \geq 0.5$ (Ant., Antipatharia sp.; BRA, Brachipoda sp. indet.; Cri, Crinoidea sp. indet.; Dem, Demospongiae sp. indet.; Nem., Nematocarcinus sp.; Oph, Ophiuroidea sp. indet; Sab, Sabellidae sp. indet.; Ser., Serpula sp.; Vir., Virgularia sp.).

Zoantharia (18). All individuals were identified to class or lower, sorted, photographed and sent to taxonomic experts for formal identifications where necessary. Two specimens of Grenadier fish preliminarily identified as Malacocephalus laevis (Lowe, 1843) and Ventrifossa sp. (Macrouridae) are likely new records for Ascension Island.

One of the most commonly encountered species found in trawls around Ascension Island were shrimps of the genus Nematocarcinus, identified as N. gracilipes (Filhol, 1884), found between depths of 500 and $1000 \mathrm{~m}$ and representing $15-40 \%$ of invertebrates larger than $0.5 \mathrm{~cm}$ collected in samples. At a depth of 700-1000 m, most of the specimens were adults, whereas at $500 \mathrm{~m}$ most were juveniles. Also identified at $500 \mathrm{~m}$ and shallower were $N$. tenuipes (Spence Bate, 1888) and N. faxoni (Burukovsky, 2001). Other crustaceans also identified included a galateid Munida sp. (likely Munida microphthalma). Shrimps including Stylopandalus richardi (Coutière, 1905) (Pandalidae) and Sergia spp. (Sergestidae) and crabs Chaceon sp. (Geryonidae) also occurred regularly, mostly on rocky habitats between 100 and $500 \mathrm{~m}$.

\section{DISCUSSIDN}

While our understanding of shallow marine ecosystems surrounding Ascension Island has only recently begun to improve (e.g. Weber et al., 2014; Brewin et al., 2016; Wirtz et al., 2017), the current study represents the first detailed examination of physical and biological characteristics of Ascension's marine environment at substantially greater depths. In addition to providing extensive fine scale bathymetric data to $1000 \mathrm{~m}$ depth, this study generates new insight into how benthic habitats and faunal community structure vary throughout Ascension's shelf area at depths of 100-1000 m. Further, the collection of biological specimens addresses the critical lack of knowledge regarding deeper-water marine biodiversity associated with this unique and isolated oceanic island.

The detailed map of seafloor topography resulting from this study enables the quantification of benthic habitat variability at a greater scale and resolution than was previously possible for Ascension Island. These data potentially provide a basis for inferring wider distribution patterns of substratum types and faunal assemblages, and for directing future oceanographic and benthic ecological research within Ascension's marine zone. Additionally, while the number of CTD deployments was limited by logistical constraints, temperature and salinity profiles spanned the range of depths sampled for benthic habitat types and faunal assemblages, representing sites lying both north and south of Ascension Island. There is still, however, much scope for the collection of additional data to characterize variation in physical oceanographic parameters in Ascension's waters in greater detail.

Our results from the SUCS image analysis showed that the average density of benthic fauna increased with substratum roughness (rugosity), perhaps not unexpected considering that the structure of marine benthic communities and habitat heterogeneity are recognized as being inextricably linked (McClain \& Barry, 2010). Further, increased habitat complexity, including roughness, is often associated with greater diversity in benthic systems (e.g. Beck, 2000; Downes et al., 2000; Thrush et al., 2001). However, we found no relationship between substratum roughness and measures of faunal diversity (richness and evenness) at the level of individual transects in the current study. Despite this result, benthic species diversity may be influenced by other habitat characteristics, such as sediment particle size diversity (Etter \& Grassle, 1992), measured at much finer scales. It should also be noted that diversity was probably underestimated in most habitats, as many cryptic or infaunal taxa are likely to have remained undetected in SUCS imagery. This bias towards more conspicuous morphotypes could in turn mask biological patterns and their relationships with environmental variables. 

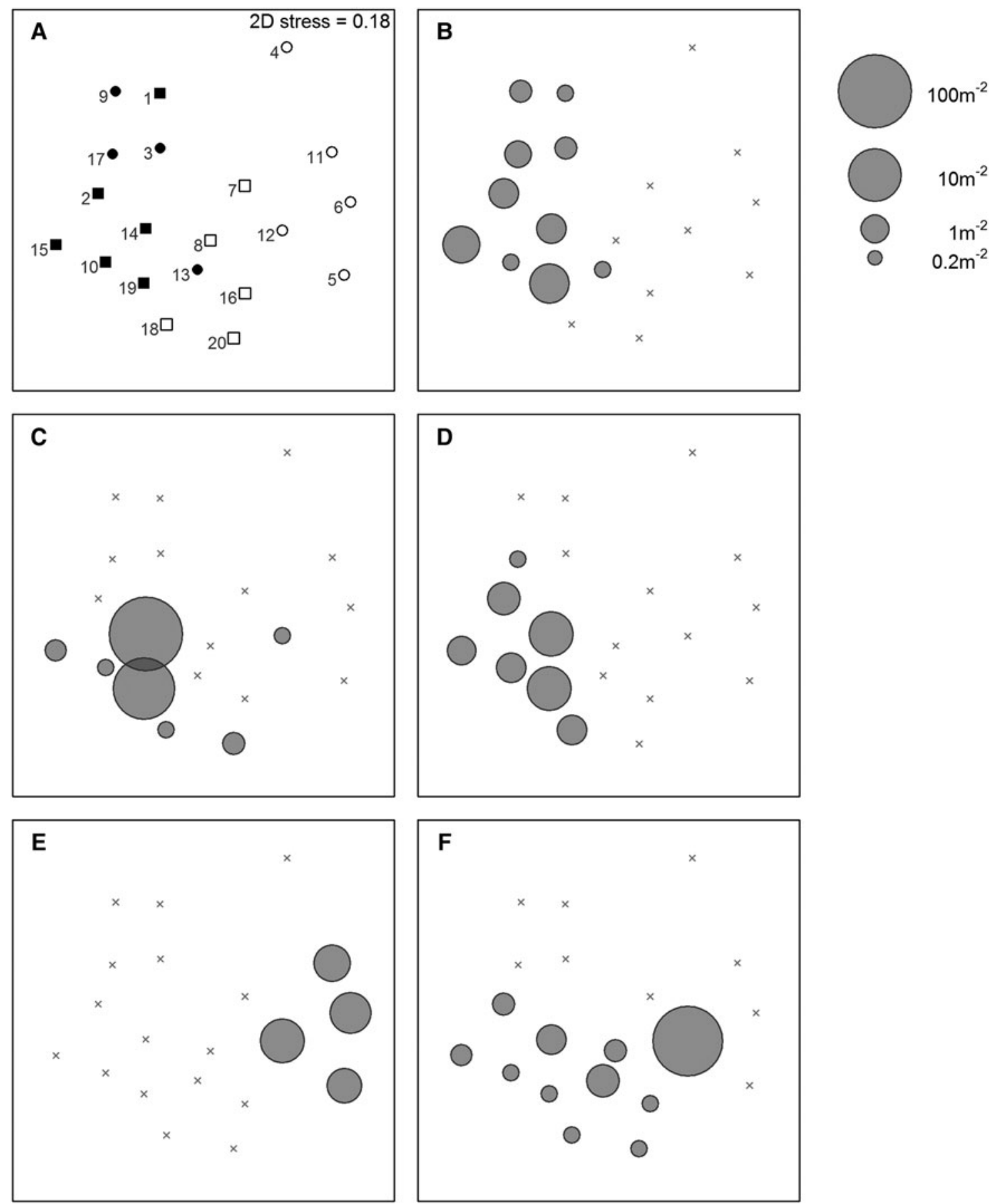

Fig. 6. (A) Non-metric MDS plot of faunal assemblage structure, based on $\log _{10}(x+1)$-transformed morphotype densities. Point labels correspond to transect number and symbols designate depth category $(\mathrm{O}, 100-249 \mathrm{~m} ; \square, 250-499 \mathrm{~m} ; \bullet \cdot, 500-750 \mathrm{~m} ; \mathbf{\square},>750 \mathrm{~m})$. (B-F) The same MDS plot with superimposed circles representing densities of morphotypes exhibiting the strongest correlations $(|\rho|>0.75)$ with CAP axes: (B) Nematocarcinus sp.; (C) Sabellidae sp. indet.; (D) Crinoidea sp. indet.; (E) Demospongiae sp. indet.; (F) Serpula sp.

While neither roughness per se nor depth were related to univariate measures of diversity, the structure of benthic faunal assemblages inhabiting Ascension Island's shelf varied according to depth and substratum type. Previous studies conducted in offshore benthic habitats at comparable depths have demonstrated the importance of depth and proportional covers of different substratum types in explaining spatial variation in faunal community structure (e.g. Buhl-Mortensen et al., 2009; Robert et al., 2014). In addition to depth, the cover of coarse sand and large pebbles appeared to be important determinants of community structure, and we identified nine faunal morphotypes driving changes in assemblage structure across benthic habitats. Black corals (Antipatharia sp.) characterized the shallowest sites, a common feature of which was a relatively high cover of complex rocky substratum, with the potential to support a diverse array of epilithic and epizootic species (Warner, 1981) such as the encrusting sponges (Demospongiae) that were also recorded in abundance.

Surveys at intermediate depths revealed diverse habitats characterized by a range of sessile and mobile species. The 
sea pen Virgularia sp. was only encountered on five transects (SUCS 3, 4, 7, 8 and 9), all of which consisted predominantly of coarse sediment - thus, there was a clear association between this species and this particular substratum type. The analysis also identified an association between sabellid polychaetes and hard substrata, as this morphotype was found at particularly high densities on SUCS transects 14 and 19 , for which the majority of photos were characterized by rocks, large rocks and boulders/bedrock. These transects, however, showed considerable heterogeneity in terms of substratum type, including a number of photos characterized by sediment, in which large numbers of sabellid polychaetes were also counted. This illustrates how species-substratum associations can depend on the spatial resolution of data (in this case, at the level of transect as opposed to individual photographs) and care should be taken when using such relationships to extrapolate across different scales (Williams et al., 2010).

The cold-water coral Lophelia cf. pertusa, encountered on around half of all transects, was recorded as deep as $1020 \mathrm{~m}$, exhibiting particularly high densities on transects shallower than $350 \mathrm{~m}$. In addition to occurring in the Pacific and Indian Oceans, L. pertusa is distributed widely throughout the Atlantic, with relatively high abundances on the continental shelves of Europe and south-eastern North America (Roberts et al., 2009). However, deep-water coral communities (including L. pertusa) are less well known from the South Atlantic (e.g. Arantes et al., 2009; Carranza et al., 2012). The current study provides the first record of substantial aggregations of reef-building scleractinian corals from Ascension Island's shelf. Currently regarded as one of the most structurally complex habitats in the deep ocean, cold-water coral reefs support high levels of biodiversity and act as potential speciation centres, while providing trophic links between the surface and seafloor and enhancing benthic carbon accumulation (Roberts et al., 2006). Owing to the ecological importance of cold-water corals and associated taxa, deep sea coral reefs are regularly categorized as Vulnerable Marine Ecosystems (VMEs; e.g. Auster et al., 2010; Jones \& Lockhart, 2011) requiring protection from destructive fishing practices and seabed extractive operations, in addition to agents of global environmental change. Our findings indicate the importance of Ascension Island in terms of supporting cold-water coral reefs, enhancing our understanding of the distribution of these ecosystems within the South Atlantic. Additional species identified during this study can also be considered as indicator taxa for VMEs, such as cup corals (Caryophyllia sp.), sea whips (Stichopathes sp.) and erect sponges.

Nematocarcinid shrimps (mostly Nematocarcinus gracilipes, with lower abundances of $N$. tenuipes and N. faxoni) were observed frequently on transects at greater depths, particularly those deeper than $500 \mathrm{~m}$, although one juvenile specimen was obtained from $\sim 250 \mathrm{~m}$. Members of this genus are widespread across the Atlantic and tend to inhabit soft muddy substrata, where they feed on detritus (Cardoso \& Burukovsky, 2014). Owing to their observed abundance at Ascension Island, Nematocarcinus spp. may provide a staple food source for deep-sea fishes and other predators. While the distribution of $N$. gracilipes is largely within the Atlantic, $N$. tenuipes can also be found in the Indian and Pacific Oceans (Burukovsky, 2003). Thus, in this case, Ascension Island represents a zone of contact among species with different, yet overlapping, regional distributions, whose coexistence may be supported by high local productivity.

Island biodiversity is expected to increase with island size, age and proximity to continents (MacArthur \& Wilson, 1963). Although Atlantic island biogeographic patterns have been evaluated for shallow marine taxa (Hachich et al., 2015), fewer generalizations can be made regarding species inhabiting deeper waters. For the relatively small, young and isolated island of Ascension, we might expect comparatively low benthic biodiversity, particularly in the context of the Atlantic Ocean and of tropical regions in general. However, with morphotype (cf. species) richness averaging $14.5 \mathrm{~m}^{-2}$ across all samples (maximum $24 \mathrm{~m}^{-2}$ ), this may not be the case, perhaps reflecting an overall latitudinal gradient of increasing benthic diversity towards the equator (Rex et al., 2000). Additionally, species inhabiting the shallow waters surrounding Ascension Island represent a unique mixture of western and eastern Atlantic taxa (De Grave et al., in press; Tsiamis et al., 2017; Wirtz et al., 2017), but in the case of deeper marine ecosystems, different processes may govern species ranges and connectivity among regions (McClain \& Hardy, 2010). The description of benthic communities and new species records arising from this study will provide valuable clues as to the biogeographic origins of deep-water taxa inhabiting the central Atlantic. On a smaller scale, while this study revealed a number of distinct benthic habitats characterized by particular faunal communities, taxonomic abundance and diversity were found to be very patchy within transects, emphasizing the importance of local variability in environmental variables in driving biological patterns. For example,

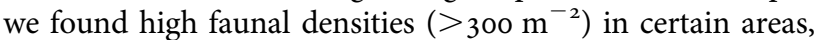
which may coincide with high productivity and/or substratum stability. Overall, the relative importance of environmental variables in structuring benthic marine communities varies according to scale (Williams et al., 2010); although the main aim of our primarily descriptive study was to characterize the physical and biological features of Ascension's shelf environment, the results will also contribute to a more general understanding of the processes structuring deep-water ecosystems.

This study has greatly enhanced our knowledge of Ascension Island's marine environment beyond $30 \mathrm{~m}$ depth. The detailed physical and biological data collected here will enable the identification of ecologically important and/or vulnerable benthic habitats, which in turn will assist in the delimitation of zones for protection. These data also constitute a critical baseline against which to assess potential future ecological responses to local- and large-scale environmental change. Deep-sea ecosystems are vital to ocean biogeochemical and ecological processes, and the loss of benthic biodiversity is a serious threat to marine ecosystem functioning (Danovaro et al., 2008). Additionally, confirmation of the identities of species collected in deep-water samples will increase biodiversity estimates and contribute to our understanding of biogeographic processes structuring Ascension's marine communities. While there is scope for further analysis of data from the current study to investigate relationships between environmental and biological variables in more detail, future surveys should aim to incorporate larger scales and greater depths to assess the generality of our findings. Overall, our understanding of the biogeography and functioning of deep-sea ecosystems remains limited, largely as a result of the technical and logistical challenges involved in collecting 
data from such large-scale, inaccessible environments. In addition to addressing this critical lack of understanding, scientific researchers must work closely with conservation bodies, industry and policymakers to ensure the successful management of these important marine ecosystems (RamirezLlodra et al., 2010).

\section{SUPPLEMENTARY MATERIAL}

The supplementary material for this article can be found at https://doi.org/10.1017/So025315417000820

\section{ACKNOWLEDGEMENTS}

This study was funded by the Blue Marine Foundation in association with a Darwin Initiative Grant (DPLUSo21), the National Environment Research Council (NERC), the British Antarctic Survey (BAS) and the South Atlantic Environmental Research Institute (SAERI). The authors gratefully acknowledge the Atlantic Meridional Transect team for their logistical support and expertise, particularly in collecting multibeam sonar data. We would also like to thank the master, officers and crew of RRS 'James Clark Ross'.

\section{REFERENCES}

Anderson M.J. and Willis T.J. (2003) Canonical analysis of principal coordinates: a useful method of constrained ordination for ecology Ecology 84, 511-525.

Arantes R.C.M., Castro C.B., Pires D.O. and Seoane J.C.S. (2009) Depth and water mass zonation and species associations of cold-water octocoral and stony coral communities in the southwestern Atlantic. Marine Ecology Progress Series 397, 71-79.

Auster P.J., Gjerde K., Heupel E., Watling L., Grehan A. and Rogers A.D. (2010) Definition and detection of vulnerable marine ecosystems on the high seas: problems with the 'move-on' rule. ICES Journal of Marine Science 68, 254-264.

Barnes D.K., Brewin P.E., Cordingley A., Doemel J., Enderlein P., Fielding S., Held C., Hogg O.T., Janosik A., Jimenez M.L., Laptikovsky V., Pearce D., Preston M., Robst J. and Sands C.J. (2011) Cruise report JR262 and 26oa: Mapping benthic biodiversity of the South Georgia continental shelf. Available at: https:/www. bodc.ac.uk/data/information_and_inventories/cruise_inventory/report/ jr262.pdf.

Barnes D.K.A., Convey P., Dömel J., Edmonston J., Enderlein P., Goodall-Copestake W., Hancox E., Hogg O.T., Klepacki J., Moreau C., Scott S. and Stowasser G. (2013) South Atlantic wilderness: assessment of Tristan da Cunha's seabed biodiversity. Available at: https://www.bodc.ac.uk/data/information_and_inventories/ cruise_inventory/report/jr287.pdf.

Beck M.W. (2000) Separating the elements of habitat structure: independent effects of habitat complexity and structural components on rocky intertidal gastropods. Journal of Experimental Marine Biology and Ecology 249, 29-49.

Bourne W.R. and Simmons K.E.L. (2001) The distribution and breeding success of seabirds on and around Ascension in the tropical Atlantic Ocean. Atlantic Seabirds 3, 187-202.

Brewin P.E., Brown J. and Brickle P. (2016) Diurnal variation of fish and macrobenthic invertebrate community structure in an isolated oceanic island of the South Atlantic. Journal of the Marine Biological Association of the United Kingdom 96, 737-747.

Buhl-Mortensen P., Dolan M. and Buhl-Mortensen L. (2009) Prediction of benthic biotopes on a Norwegian offshore bank using a combination of multivariate analysis and GIS classification. ICES Journal of Marine Science: Journal du Conseil 66, 2026-2032.

Burukovsky R.N. (2003) Shrimps of the family Nematocarcinidae. Kaliningrad: Kaliningrad State Technical University.

Cardoso I.A. and Burukovsky R.N. (2014) Nematocarcinus Milne Edwards, 1881 (Crustacea, Decapoda) from Southwestern Atlantic, including the Southern Mid-Atlantic Ridge area. Zootaxa 3887, 437-458.

Carranza A., Recio A.M., Kitahara M., Scarabino F., Ortega L., López G., Franco-Fraguas P., De Mello C., Acosta J., Fontan A. and Grupo Miguel Oliver Uruguay o110 (2012) Deep-water coral reefs from the Uruguayan outer shelf and slope. Marine Biodiversity 42, $411-414$.

Cavalcanti G.S., Gregoracci G.B., dos Santos E.O., Silveira C.B., Meirelles P.M., Longo L., Gotoh K., Nakamura S., Iida T., Sawabe T., Rezende C.E., Francini-Filho R.B., Moura R.L., Amado-Filho G.M. and Thompson F.L. (2014) Physiologic and metagenomic attributes of the rhodoliths forming the largest $\mathrm{CaCO}_{3}$ bed in the South Atlantic Ocean. ISME Journal 8, 52-62.

Clarke K.R. and Ainsworth M. (1993) A method of linking multivariate community structure to environmental variables. Marine Ecology Progress Series 92, 205-219.

Danovaro R., Gambi C., Dell'Anno A., Corinaldesi C., Fraschetti S., Vanreusel A., Vincx M. and Gooday A.J. (2008) Exponential decline of deep-sea ecosystem functioning linked to benthic biodiversity loss. Current Biology 18, 1-8.

De Grave S., Anker A., Dworschak P.C., Clark P.F. and Wirtz P. (in press) An updated checklist of the marine Decapoda of Ascension Island, central Atlantic Ocean. Journal of the Marine Biological Association of the United Kingdom. doi: 10.1017/Soo25315414001295.

Downes B.J., Lake P.S., Schreiber E.S.G. and Glaister A. (2000) Habitat structure, resources and diversity: the separate effects of surface roughness and macroalgae on stream invertebrates. Oecologia 123, 569-581.

Etter R.J. and Grassle J.F. (1992) Patterns of species diversity in the deep sea as a function of sediment particle size diversity. Nature $360,576-578$.

Floeter S.R., Rocha L.A., Robertson D.R., Joyeux J.C., Smith-Vaniz W.F., Wirtz P., Edwards A.J., Barreiros J.P., Ferreira C.E.L., Gasparini J.L., Brito A., Falcon J.M., Bowen B.W. and Bernardi G. (2007) Atlantic reef fish biogeography and evolution. Journal of Biogeography 35, 22-47.

Hachich N.F., Bonsall M.B., Arraut E.M., Barneche D.R., Lewinsohn T.M. and Floeter S.R. (2015) Island biogeography: patterns of marine shallow-water organisms in the Atlantic Ocean. Journal of Biogeography 42, 1871-1882.

Jicha B.R., Singer B.S. and Valentine M.J. (2013) ${ }^{40} \mathrm{Ar} /{ }^{39} \mathrm{Ar}$ geochronology of subaerial Ascension Island and a re-evaluation of the temporal progression of basaltic to rhyolitic volcanism. Journal of Petrology 54, $2581-2596$

Jones C.D. and Lockhart S.J. (2011) Detecting Vulnerable Marine Ecosystems in the Southern Ocean using research trawls and underwater imagery. Marine Policy 35, 732-736.

Legendre P. and Legendre L. (2012) Numerical ecology, 3rd edition. Amsterdam: Elsevier.

MacArthur R.H. and Wilson E.O. (1963) An equilibrium theory of insular zoogeography. Evolution 17, 373-387. 
Macaya E.C., Riosmena-Rodríguez R., Melzer R.R., Meyer R., Försterra G. and Häussermann V. (2015) Rhodolith beds in the South-East Pacific. Marine Biodiversity 45, 153-154.

Manning R.B. and Chace F.A. (1990) Decapod and stomatopod crustacea from Ascension Island, South Atlantic Ocean. Smithsonian Contributions to Zoology 503, 91 pp.

McClain C.R. and Barry J.P. (2010) Habitat heterogeneity, disturbance, and productivity work in concert to regulate biodiversity in deep submarine canyons. Ecology 91, 964-976.

McClain C.R. and Hardy S.M. (2010) The dynamics of biogeographic ranges in the deep sea. Proceedings of the Royal Society B: Biological Sciences 277, 3533-3546.

Neill K.F., Nelson W.A., D’Archino R., Leduc D. and Farr T.J. (2015) Northern New Zealand rhodoliths: assessing faunal and floral diversity in physically contrasting beds. Marine Biodiversity 45, 63-75.

Nelson W.A. (2009) Calcified macroalgae - critical to coastal ecosystems and vulnerable to change: a review. Marine and Freshwater Research $60,787-801$.

Oksanen J., Blanchet F.G., Kindt R., Legendre P., Minchin P.R., O’Hara R.B., Simpson G.L., Solymos P., Stevens M.H.H. and Wagner H. (2016) vegan: community ecology package. R package version 2.3-5.

Price J.H. and John D.M. (1980) Ascension Island: a survey of inshore benthic macroorganisms, communities and interactions. Aquatic Botany 9, 251-278.

Ramirez-Llodra E., Brandt A., Danovaro R., De Mol B., Escobar E., German C., Levin L., Arbizu P., Menot L. and Buhl-Mortensen P. (2010) Deep, diverse and definitely different: unique attributes of the world's largest ecosystem. Biogeosciences 7, 2851-2899.

R Core Team (2015) R: a language and environment for statistical computing. Vienna: R Foundation for Statistical Computing. Available at https://www.R-project.org/.

Rex M.A., Stuart C.T. and Coyne G. (2000) Latitudinal gradients of species richness in the deep-sea benthos of the North Atlantic Proceedings of the National Academy of Sciences USA 97, 4082-4085.

Robert K., Jones D.O. and Huvenne V.A. (2014) Megafaunal distribution and biodiversity in a heterogeneous landscape: the iceberg scoured Rockall Bank, NE Atlantic. Marine Ecology Progress Series $501,67-88$
Roberts J.M., Wheeler A.J. and Freiwald A. (2006) Reefs of the deep: the biology and geology of cold-water coral ecosystems. Science 312, 543-547.

Roberts J.M., Wheeler A.J., Freiwald A. and Cairns S. (2009) Cold-water corals: the biology and geology of deep-sea coral habitats. Cambridge: Cambridge University Press.

Thrush S.F., Hewitt J.E., Funnell G.A., Cummings V.J., Ellis J., Schultz D., Talley D. and Norkko A. (2001) Fishing disturbance and marine biodiversity: the role of habitat structure in simple soft-sediment systems. Marine Ecology Progress Series 223, 277-286.

Torrano-Silva B.N., Ferreira S.G. and Oliveira M.C. (2015) Unveiling privacy: advances in microtomography of coralline algae. Micron 72 , $34-38$.

Tsiamis K., Peters A.F., Shewing D.M., Asensi A.O., Van West P. and Küpper F.C. (2017) Marine benthic algal flora of Ascension Island, South Atlantic. Journal of the Marine Biological Association of the United Kingdom 97, 681-688.

Warner G.F. (1981) Species descriptions and ecological observations of black corals (Antipatharia) from Trinidad. Bulletin of Marine Science $31,147-163$

Weber S.B., Weber N., Ellick J., Avery A., Frauenstein R., Godley B.J., Sim J., Williams N. and Broderick A.C. (2014) Recovery of the South Atlantic's largest green turtle nesting population. Biodiversity Conservation 23, 3005-3018.

Williams A., Althaus F., Dunstan P.K., Poore G.C., Bax N.J., Kloser R.J. and McEnnulty F.R. (2010) Scales of habitat heterogeneity and megabenthos biodiversity on an extensive Australian continental margin (100-1100 m depths). Marine Ecology 31, 222-236.

and

Wirtz P., Bingeman J., Bingeman J., Fricke R., Hook T.J. and Young J. (2017) The fishes of Ascension Island, central Atlantic Ocean - new records and an annotated checklist. Journal of the Marine Biological Association of the United Kingdom 97, 783-798.

\section{Correspondence should be addressed to:} P. Brickle South Atlantic Environmental Research Institute, Stanley, Falkland Islands email: pbrickle@env.institute.ac.fk 